\title{
Characteristics of Laryngeal Osteosarcoma: A Critical Review
}

Antti A. Mäkitie · Kenneth O. Devaney · Bertrand Baujat •

Alhadi Almangush · Alfio Ferlito

Received: January 13, 2020 / Published online: February 11, 2020

(C) The Author(s) 2020

\section{ABSTRACT}

Laryngeal sarcomas constitute an extremely rare entity among head and neck malignancies. Furthermore, most of them are chondrosarcomas, and the osteogenic form remains a true rarity. In general, there is a lack of information on the characteristics of laryngeal osteosarcoma. Thus, we sought to critically review the existing world literature on laryngeal osteosarcoma in order to develop a more accurate clinicopathological profile of this malignancy.

This article was written by members and invitees of the International Head and Neck Scientific Group (http:// www.IHNSG.com).

Enhanced Digital Features To view enhanced digital features for this article go to https://doi.org/10.6084/ m9.figshare.11770362.

A. A. Mäkitie (弗)

Department of Otorhinolaryngology, Head and Neck Surgery, University of Helsinki and Helsinki University Hospital, Helsinki, Finland

e-mail: antti.makitie@helsinki.fi

\section{A. A. Mäkitie}

Research Program in Systems Oncology, Faculty of Medicine, University of Helsinki, Helsinki, Finland

\section{A. A. Mäkitie}

Division of Ear, Nose and Throat Diseases, Department of Clinical Sciences, Intervention and Technology, Karolinska Institutet and Karolinska Hospital, Stockholm, Sweden
Laryngeal osteosarcoma has a predilection for elderly male patients, as $87 \%$ were male in the present series and the mean age was 62 years (range 32-80), and without a direct association with tobacco exposure. Osteosarcoma of the larynx is typically a highly malignant neoplasm that metastasizes early, has a propensity for hematogenous spread and also has a marked tendency to recur. Twelve (41\%) out of the 29 cases in the present review with follow-up data had metastatic disease. The aspects that distinguish osteosarcoma from its differential diagnostic alternatives are discussed in this review.

Keywords: Larynx; Osteosarcoma; Radiotherapy; Sarcoma; Surgery

\author{
A. A. Mäkitie · B. Baujat \\ Sorbonne université, Service d'oto-rhino- \\ laryngologie et de chirurgie cervicofaciale, DMU \\ CHIR, Hôpital Tenon, Assistance-Publique-Hôpitaux \\ de Paris, 4, rue de la Chine, 75020 Paris, France \\ K. O. Devaney \\ Department of Pathology, Allegiance Health, \\ Jackson, MI, USA \\ B. Baujat \\ EURACAN (European Rare Cancer Network) Group \\ 7 Head and Neck rare tumours, Paris, France
}




\section{Key Summary Points}

Laryngeal sarcomas constitute an extremely rare entity among head and neck malignancies.

Osteosarcoma of the larynx is typically a highly malignant neoplasm that metastasizes early, has a propensity of hematogenous spread and also has a marked tendency to recur.

A full photomicrographic documentation is essential for the diagnosis and registration of osteosarcoma cases.

The diagnosis of this highly malignant tumor would preferably warrant an international consultation network including a registry of rare head and neck neoplasms.

\section{INTRODUCTION}

Despite being the most common primary malignant neoplasm of the bony skeleton, osteosarcoma is one of the rarest malignant mesenchymal neoplasms of the larynx. Sarcomas encountered in the larynx are usually chondrosarcomas. Therefore, even physicians

B. Baujat

REFCOR (Réseau d'Expertise Français sur les cancers ORL Rares), Paris, France

A. Almangush

Department of Pathology, University of Helsinki, Helsinki, Finland

A. Almangush

Department of Oral and Maxillofacial Diseases,

University of Helsinki, Helsinki, Finland

A. Almangush

Institute of Dentistry, University of Misurata,

Misurata, Libya

A. Ferlito

Coordinator of the International Head and Neck

Scientific Group, Padua, Italy in referral-based academic centers of pathology or otorhinolaryngology-head and neck surgery may encounter only a single patient with a true laryngeal osteosarcoma in their entire career. Of note, we searched the REFCOR database (réseau d'Expertise Français sur les Cancers ORL Rares [French Network of Rare Head and Neck Tumors]) in order to find cases to report in the present review. The REFCOR has been registering rare head and neck cancers, i.e., rare cancers of the aerodigestive tract excluding squamous cell carcinoma and undifferentiated nasopharyngeal carcinoma, and cancers of the salivary glands, ear, nasal cavities, and sinus, since 2008. Out of the 7530 patients registered up to August 2019 , only 54 osteosarcoma cases were diagnosed, and none of these was located in the larynx.

Laryngeal osteosarcoma was first described by Jackson and Jackson in 1942 without histological documentation [1]. In 1946, Clerf et al. reported eight cases of sarcoma of the larynx, and one of these was classified as fibro-osteosarcoma, but the photomicrograph of the tumor was not convincing [2]. The first welldocumented case of laryngeal osteosarcoma was described by Sprinkle et al. in 1966 [3]. Of note, in 1974, the textbook Tumors of the Head and Neck: Clinical and Pathological Considerations by Batsakis concluded that no authentic case of osteosarcoma in the upper respiratory tract, including the larynx, had been reported at that time [4]. In 2017, Bennion et al. reported 33 laryngeal osteosarcomas having been reported in the English literature since 1942, but many of the reports listed in their review, including their own cases, did not present pathological documentation [5].

It is noteworthy that morphological features of sarcomas typically represent a heterogeneous variation in morphology. This will lead to challenging differential diagnostic considerations, especially when the obtained biopsies remain small. In contrast to a low-grade chondrosarcoma-in which a limited biopsy specimen may still leave open the question of the malignant nature of that lesion-it is usually quite apparent for the pathologist that a laryngeal osteosarcoma specimen represents a highgrade malignancy. More importantly, the 
precise subclassification of the malignancy will need to be determined.

The existing reports of laryngeal osteosarcoma cases do not consistently include pathological documentation that would allow critical evaluation of the final pathological diagnosis. Therefore, our primary aim was to create a current series of all the published laryngeal osteosarcoma cases by critically evaluating the published reports of this rare malignancy and to include only those cases with adequate pathological description of the findings. The secondary aim was to obtain comprehensive information regarding the characteristics of these neoplasms to enable a discussion of possibilities for enhancing their diagnostic accuracy.

\section{METHODS}

We conducted a literature search in the PubMed database using the following keywords: "Laryngeal" OR "Larynx" AND "Osteosarcoma". The search covered all years from the origin of the database until 31 December 2019. The Preferred Reporting Items for Systematic Review and Meta-Analysis (https://www.equatornetwork.org/) methodology was applied. A total of 61 hits were retrieved (Fig. 1). Of these, 30 publications were relevant as having reported a new case/s of laryngeal osteosarcoma $(N=33)$ that met the inclusion criteria of providing proper pathological evaluation and photomicrographic documentation of the finding. Cases that did not meet these inclusion criteria were excluded. This article is based on previously conducted studies and does not contain any studies with human participants or animals performed by any of the authors.

\section{RESULTS AND DISCUSSION}

\section{Clinical Features of the Reported Cases in the Literature}

Many reports indicate that this neoplasm occurs in men in their sixth and eighth decades of life, and that the lesion is not directly associated with alcohol or tobacco exposure [6, 7]. Laskin et al. and Sheen et al. reported two patients with a history of radiotherapy prior to the development of laryngeal osteosarcoma $[8,9]$. These tumors usually arise from the vocal cord and cricoid cartilage. Therefore, the most common symptoms are hoarseness, dyspnea, and obstruction.

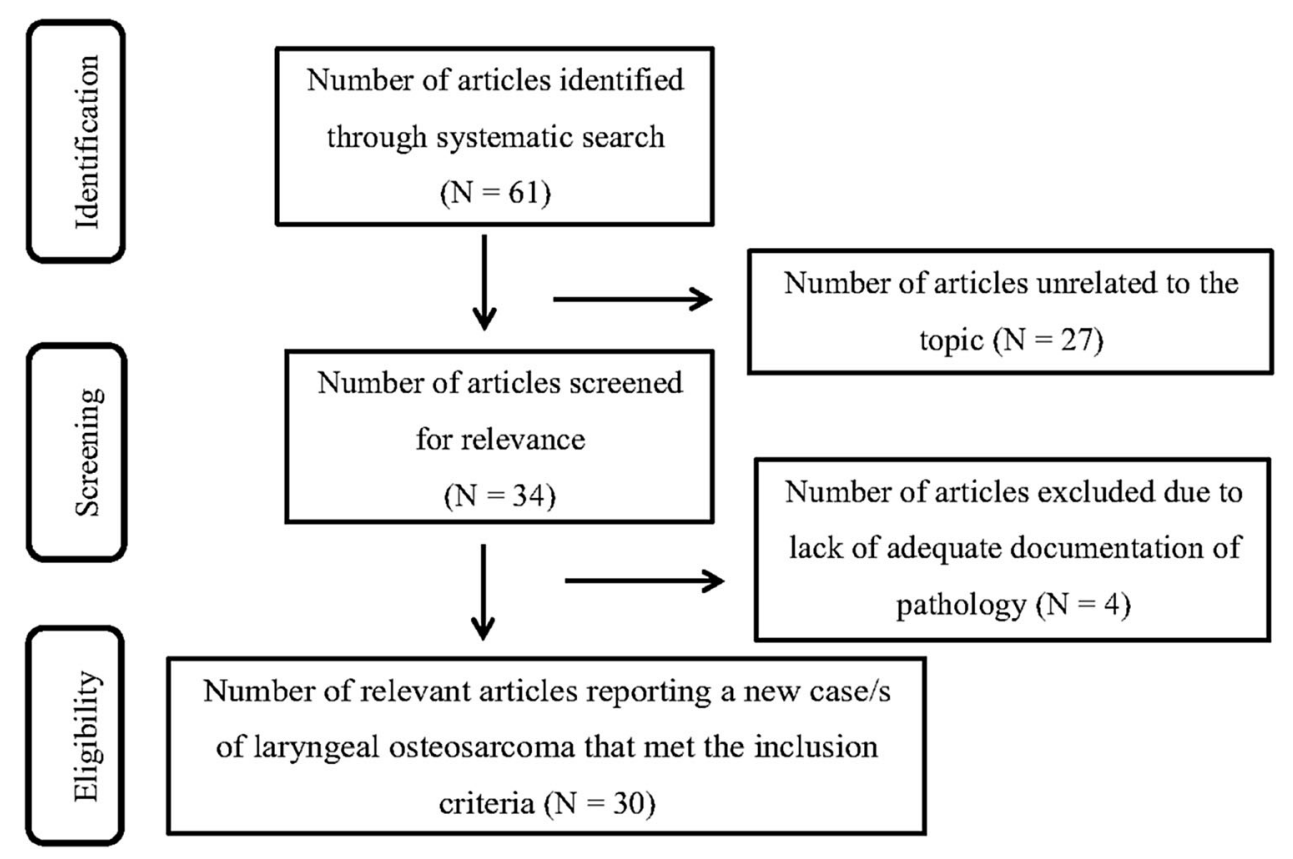

Fig. 1 Flow chart describing the PRISMA search 
The tumors included in this review and with information on the exact location $(N=22)$ involved either subglottic [2], supraglottic [3] or transglottic [2] structures, vocal cords [10], or thyroid and/or cricoid cartilages [6].

Osteosarcoma is typically a highly malignant neoplasm that metastasizes early, with a propensity for hematogenous spread and also a marked tendency to recur. There are reports of metastases to regional lymph nodes, but these remain rare, and instead, hematogenous spread to the lungs is the main route. In the present review, 12 out of the 33 patients were diagnosed with distant metastases, most frequently in the lungs. Seventeen out of the 25 patients with follow-up data available in the published case reports had experienced persistent or early recurrent disease, typically within 1-2 years.

\section{Pathology of Laryngeal Osteosarcoma}

Macroscopically, the neoplasm is mainly polypoid or exophytic in appearance but may also mimic other sarcomas. The gross specimen is typically grainy and, in some areas, difficult or impossible to cut with a scalpel because of its ossification. The tissue may have a variable color ranging from yellow to brown or red.

Microscopically, the tumor is composed of frankly malignant, spindle-shaped mesenchymal cells, associated with osteoid and immature neoplastic bone formation, as was shown in the reviewed reports (Fig. 2). The nuclei show considerable hyperchromasia or pleomorphism, and mitoses may be numerous. Atypical and bizarre giant cells and multinucleated osteoclast-like cells have been described. Venous invasions may be identified.

Immunohistochemical staining has shown that the neoplasm is positive for vimentin and negative for desmin, S-100 protein, cytokeratin (AE1/AE3, MNF-116, CK5/6, CK7, CK8, CK19, CK20), and epithelial membrane antigen. Both osteonectin and osteocalcin are expressed in osteogenic sarcoma but are not sufficiently specific. However, osteonectin and osteocalcin will highlight osteoid matrix and distinguish it from collagen matrix.

Electron microscopy studies [10-12] have shown cells resembling osteoblasts with

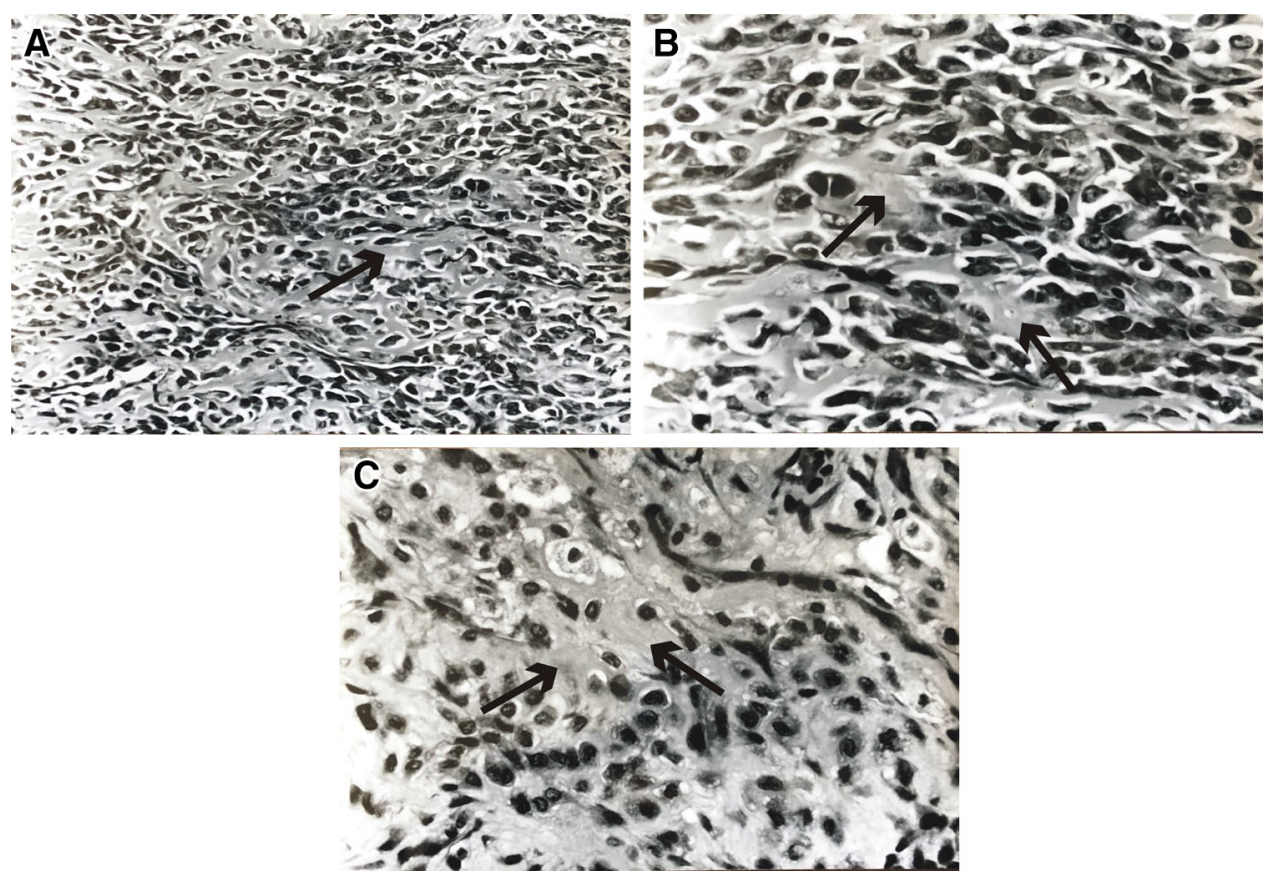

Fig. 2 a Laryngeal osteosarcoma with osteoid formations (arrow) produced by malignant cells (hematoxylin-eosin). b Osteoid formation (arrows) by the tumor cells is readily apparent and confirms the diagnosis of osteosarcoma (hematoxylin-eosin). c Another area of the tumorproducing osteoid (arrows) (hematoxylin-eosin) 
pleomorphic nuclei and nucleoli of variable size within the abundant cytoplasm containing numerous dilated cisternae of rough endoplasmic reticulum. The cells were enveloped by interlacing collagen fibers. Osteoblastic elements predominated but cartilaginous and fibrous tissue could also be found. No desmosomes or other evidence of epithelial differentiation was found in the tumor.

\section{Diagnosis of Laryngeal Osteosarcoma}

The definite diagnosis of osteosarcoma depends on the identification of osteoid production by malignant cells in the biopsy sample, as was shown in the reviewed reports. The differential diagnosis includes spindle-cell squamous carcinoma with osteoid differentiation, chondrosarcoma, malignant fibrous histiocytoma, fibrosarcoma, and myositis ossificans affecting the larynx. Spindle-cell squamous carcinoma may contain benign and rarely malignant osteoid areas [13]. Therefore, older reports of laryngeal osteosarcoma may represent spindlecell squamous carcinoma with osteoid formation. Any bone-producing malignant mesenchymal lesion should at first be suspected as a spindle-cell carcinoma. The presence of islands of carcinoma in situ or microinfiltrating carcinoma excludes the diagnosis of osteosarcoma.

In osteogenic sarcoma, clearly sarcomatous areas are present, and the "zonal phenomenon"-which is characterized by a central cellular area, an intermediate zone of osteoid formation, and a peripheral shell of highly organized bone-is absent. The phenomenon of formation of mature bone is most prominent in the periphery of the lesion and is an important criterion for differentiating myositis ossificans from osteogenic sarcoma. In this latter lesion, mature osteoids are located in the center of neoplasm, and neoplastic mesenchymal cellsthat form the osteoids-are in the periphery.

Osteogenic sarcoma metastatic to larynx has also been reported $[14,15]$. This unlikely event can be ruled out with clinical assessment of the patient.

\section{Treatment and Prognosis}

Wide local resection with clear margins, which typically warrants total laryngectomy, remains the treatment of choice for laryngeal osteosarcoma to achieve local control and long-term

Table 1 Key features of laryngeal osteosarcoma

\section{Rarity}

Demographics

Large lesions arising predominantly in men in their sixth to eight decades

Histology

High-grade sarcoma with area of osteoid production by the tumor cells at least focally

Chondroid elements may be present, as may areas reminiscent of fibrosarcoma, malignant

Fibrous histiocytoma, or sarcoma (not further subclassified)

Immunohistochemical staining can be utilized and will add to the histological diagnosis

Differential diagnosis

Spindle-cell squamous carcinoma with osteoid differentiation, chondrosarcoma, malignant fibrous histiocytoma, fibrosarcoma, and myositis ossificans

Prognosis

Laryngeal osteosarcoma usually results in death in less than 2 years from either extensive local disease or pulmonary metastases 
Table 2 Cases of laryngeal osteosarcoma with pathological documentation

\begin{tabular}{|c|c|c|c|c|}
\hline Institute & Authors & Year & Characteristics and treatment & Follow-up \\
\hline $\begin{array}{l}\text { University of Washington, Seattle, } \\
\text { WA, USA }\end{array}$ & $\begin{array}{l}\text { Mantilla et al. } \\
\text { [38] }\end{array}$ & 2019 & $\begin{array}{l}\text { 75/M. Former smoker. Progressive } \\
\text { hoarseness. Anterior commissure } \\
\text { High-grade. No invasion of TC. No } \\
\text { Metastasis. LE }\end{array}$ & Lost to follow-up \\
\hline Rashid Hospital, Dubai & $\begin{array}{l}\text { AbdullGaffar } \\
\text { and Keloth } \\
{[16]}\end{array}$ & 2018 & $\begin{array}{l}\text { 32/F. Non-smoker. Hoarseness for } \\
1.5 \text { months }\end{array}$ & Lost to follow-up \\
\hline Chandigarh, India & Bahl et al. [6] & 2015 & $\begin{array}{l}\text { 50/M. Hoarseness for } 2 \text { months } \\
\text { Transglottic. No metastases. LE, } \\
\text { thyroidectomy, partial } \\
\text { pharyngectomy. CT }\end{array}$ & NED at 9 months \\
\hline $\begin{array}{l}\text { Nicolaus Copernicus University, } \\
\text { Torun, Poland }\end{array}$ & $\begin{array}{l}\text { Sawicki et al. } \\
\quad[17]\end{array}$ & 2015 & $\begin{array}{l}\text { 58/F. Dyspnea for } 6 \text { months } \\
\text { Subglottic. Immobile VC. No } \\
\text { metastases. LE }\end{array}$ & NED $>22$ months \\
\hline $\begin{array}{l}\text { Tygerberg Hospital, Cape Town, } \\
\text { South Africa }\end{array}$ & $\begin{array}{l}\text { Mosalleum et al. } \\
\text { [7] }\end{array}$ & 2015 & $\begin{array}{l}\text { Dysphonia, dyspnea for } 4 \text { months. } \\
\text { LE }\end{array}$ & $\begin{array}{l}\text { Bilateral lung } \\
\text { metastases at } \\
8 \text { months }\end{array}$ \\
\hline $\begin{array}{l}\text { Saitama Medical University, } \\
\text { International Medical Center, } \\
\text { Hidaka, Saitama, Japan }\end{array}$ & Kuba et al. [18] & 2015 & $\begin{array}{l}\text { Neck mass } \\
\text { High-grade osteoblastic OS } \\
\text { No metastases. Partial LE }\end{array}$ & NED at 20 months \\
\hline Baroda, Gujarat, India & Bhatt et al. [19] & 2014 & $\begin{array}{l}\text { 38/M. Smoker. Hoarseness for } \\
2 \text { months. No metastases } \\
\text { Near-total LE }\end{array}$ & NED at 15 months \\
\hline Istanbul University, Turkey & $\begin{array}{l}\text { Ulusan et al. } \\
\text { [20] }\end{array}$ & 2012 & $\begin{array}{l}\text { 59/M. Smoker. Hoarseness and } \\
\text { dyspnea. Anterior commissure } \\
\text { Radiation-induced OS (RT } 5 \text { years } \\
\text { earlier). Normal chest, abdominal, } \\
\text { and bone radiographs. No } \\
\text { metastasis } \\
\text { LE }\end{array}$ & NED at 8 years \\
\hline
\end{tabular}


Table 2 continued

\begin{tabular}{|c|c|c|c|c|}
\hline Institute & Authors & Year & Characteristics and treatment & Follow-up \\
\hline Tabriz University Tabriz, Iran & $\begin{array}{l}\text { Sanaat et al. } \\
\text { [21] }\end{array}$ & 2009 & $\begin{array}{l}\text { Dyspnea, dysphagia, and } \\
\text { odynophagia } \\
\text { Solid mass destroying both cords } \\
\text { with supra- and subglottic } \\
\text { extension } \\
\text { Bone and lung metastases. LE }\end{array}$ & $\begin{array}{l}\text { DOD at } \\
12 \text { months }\end{array}$ \\
\hline $\begin{array}{l}\text { Sisli Etfal Education \& Research, } \\
\text { Hospital, Department of } \\
\text { Radiation Oncology, Istanbul, } \\
\text { Turkey }\end{array}$ & $\begin{array}{l}\text { Arslan et al. } \\
{[22]}\end{array}$ & 2008 & $\begin{array}{l}\text { 69/M. Larynx. NOS. Persistent } \\
\text { hoarseness. LE and postoperative } \\
\text { RT. Neck recurrence } 5 \text { months } \\
\text { later } \\
\text { Lung and neck metastases }\end{array}$ & DOD \\
\hline $\begin{array}{l}\text { Hospital San Giovanni, di Dio e } \\
\text { Ruggi d'Aragona, Via San } \\
\text { Leonardo, Salerno, Italy }\end{array}$ & $\begin{array}{l}\text { Mottola et al. } \\
\text { [23] }\end{array}$ & 2008 & $\begin{array}{l}\text { 56/M. Non-smoker. TC, CC, and } \\
\text { paratracheal space. Dyspnea, } \\
\text { dysphagia, and dysphonia. Tumor } \\
\text { mass affecting glottis and } \\
\text { supraglottis. LE }\end{array}$ & DOD 3 months \\
\hline $\begin{array}{l}\text { Oddział Otolaryngologiczny Szpitala } \\
\text { im. F. Raszei w Poznaniu }\end{array}$ & $\begin{array}{l}\text { Rydzewki et al. } \\
{[24]}\end{array}$ & 2005 & $\begin{array}{l}\text { Bilateral neck and lung metastases } \\
\text { LE, ND, and CT }\end{array}$ & DOD \\
\hline $\begin{array}{l}\text { University of Texas, Southwestern } \\
\text { Medical Center, Dallas, TX, USA }\end{array}$ & Athré et al. [25] & 2005 & $\begin{array}{l}\text { 69/F. Progressive dyspnea. Larynx, } \\
\text { strap muscles, and thyroid gland } \\
\text { Dystrophic calcification outside } \\
\text { laryngeal confines. Total LE, } \\
\text { pharyngectomy, esophagectomy } \\
\text { Lung metastasis }\end{array}$ & $\begin{array}{l}\text { DOD at } \\
10 \text { months }\end{array}$ \\
\hline $\begin{array}{l}\text { Departments of ORL and Pathology } \\
\text { Okmeydan1 Training Hospital, } \\
\text { Istanbul, Turkey }\end{array}$ & $\begin{array}{l}\text { Topaloglu et al. } \\
{[26]}\end{array}$ & 2004 & $\begin{array}{l}\text { 80/M. RVC, LVC, and ventricular } \\
\text { bands. Hoarseness, progressive } \\
\text { dyspnea. Soft tissue mass } \\
\text { narrowing the airway. Extended } \\
\text { LE }\end{array}$ & NED 15 months \\
\hline \multirow[t]{2}{*}{$\begin{array}{l}\text { M.D. Anderson Cancer Center, } \\
\text { Houston, TX, US }\end{array}$} & $\begin{array}{l}\text { Madrigal et al. } \\
\text { [27] }\end{array}$ & 2002 & $\begin{array}{l}\text { 50/M. RVC. Hoarseness. Partial } \\
\text { frontolateral LE }\end{array}$ & NED at 24 months \\
\hline & & & $\begin{array}{l}\text { 59/M. Smoker. TC. Hoarseness. } \\
\text { Destructive lesion of the TC } \\
\text { extending to parapharyngeal soft } \\
\text { tissue. Total LE, CRT. Multiple } \\
\text { lung metastases }\end{array}$ & $\begin{array}{l}\text { DOD } 18 \text { at } \\
\text { months }\end{array}$ \\
\hline
\end{tabular}


Table 2 continued

\begin{tabular}{|c|c|c|c|c|}
\hline Institute & Authors & Year & Characteristics and treatment & Follow-up \\
\hline & & & $\begin{array}{l}\text { 60/M. Smoker. Polypoid mass of the } \\
\text { RVC with anterior commissure } \\
\text { extension. Dyspnea. LE and CRT } \\
\text { Neck recurrence } 10 \text { months later } \\
\text { 69/M. Smoker. True vocal cord } \\
\text { Dyspnea, dysphonia, and cough } \\
\text { Lung metastases }\end{array}$ & NED at 60 months \\
\hline Ohio State University, OH, USA & Rossi et al. [28] & 1998 & $\begin{array}{l}\text { 68/M. Former smoker } \\
\text { Wide-field LE. Lung metastases }\end{array}$ & DOD at 3 months \\
\hline $\begin{array}{l}\text { The Long Island Jewish Medical } \\
\text { Center. The Long Island Campus } \\
\text { of the Albert Einstein College of } \\
\text { Medicine, New Hyde Park, NY, } \\
\text { USA }\end{array}$ & $\begin{array}{l}\text { Myssiorek et al. } \\
\text { [29] }\end{array}$ & 1998 & $\begin{array}{l}\text { Destructive lesion of TC with } \\
\text { extension into soft tissues. } \\
\text { LE. Bone metastasis }\end{array}$ & $\begin{array}{l}\text { DOD at } \\
12 \text { months }\end{array}$ \\
\hline $\begin{array}{l}\text { University of Pittsburgh, Medical } \\
\text { Center, Pittsburgh, PA, USA }\end{array}$ & Berge et al. [30] & 1998 & $\begin{array}{l}\text { 60/F. Non-smoker. CC. Dysphonia, } \\
\text { dysphagia, and weight loss } \\
\text { Expansion of the medullary portion } \\
\text { of the cricoid cartilage with } \\
\text { encroachment on the airway } \\
\text { LE and ND }\end{array}$ & NED at 44 months \\
\hline $\begin{array}{c}\text { National Taiwan University } \\
\text { Hospital, Taipei, Taiwan }\end{array}$ & Sheen et al. [9] & 1997 & $\begin{array}{l}\text { 56/M. RT for nasopharyngeal } \\
\text { carcinoma } 32 \text { years earlier } \\
\text { Left neck and anterior TC } \\
\text { Hoarseness. Hyperdense mass in the } \\
\text { left upper neck. LE }\end{array}$ & $\begin{array}{l}\text { DOD at } \\
21 \text { months }\end{array}$ \\
\hline Institute AFIP & $\begin{array}{l}\text { Devaney and } \\
\text { Ferlito }[31]\end{array}$ & 1996 & Pathology consultation case & Lost to follow-up \\
\hline $\begin{array}{l}\text { Hasharon Hospital, Golda Medical } \\
\text { Center, Petah Tikva }\end{array}$ & $\begin{array}{l}\text { Zohar et al. } \\
\text { [32] }\end{array}$ & 1996 & Surgery & Lost to follow-up \\
\hline $\begin{array}{l}\text { Centre Hospitalier Universitaire, de } \\
\text { Bordeaux, France }\end{array}$ & $\begin{array}{l}\text { Pinsolle et al. } \\
\text { [12] }\end{array}$ & 1990 & $\begin{array}{l}\text { 65/M. Former smoker. Dyspnea, } \\
\text { dysphonia. } 1.5 \mathrm{~cm} \text { polypoid tumor } \\
\text { involving the RVC and anterior } \\
\text { commissure. RT }\end{array}$ & NED at 60 months \\
\hline
\end{tabular}


Table 2 continued

\begin{tabular}{|c|c|c|c|c|}
\hline Institute & Authors & Year & Characteristics and treatment & Follow-up \\
\hline & & & Recurrence after 1 month & \\
\hline & & & Resection and pectoralis flap & \\
\hline \multirow[t]{3}{*}{ University of Liverpool, England } & $\begin{array}{l}\text { Van Laer et al. } \\
\text { [33] }\end{array}$ & 1989 & 75/M. LVC and left pyriform fossa & $\begin{array}{l}\text { Recurrence at } \\
13 \text { months }\end{array}$ \\
\hline & & & Dysphagia, discomfort in the throat & \\
\hline & & & Amorphous mass of calcification. LE & \\
\hline $\begin{array}{l}\text { Pathologisches Institut Oldenburg, } \\
\text { Germany }\end{array}$ & $\begin{array}{l}\text { Remagen et al. } \\
{[34]}\end{array}$ & 1983 & 65/M. LVC. RT. Recurrent disease & $\begin{array}{l}\text { DOD at } \\
24 \text { months }\end{array}$ \\
\hline \multirow[t]{3}{*}{ Mayo Clinic, Rochester, NY, USA } & $\begin{array}{l}\text { Gorenstein } \\
\text { et al. [35] }\end{array}$ & 1980 & 75/M. RVC and ventricle & $\begin{array}{l}\text { DOD at } \\
14 \text { months }\end{array}$ \\
\hline & & & Hoarseness 5 months. LE and ND & \\
\hline & & & Local and distant metastases & \\
\hline $\begin{array}{l}\text { Mahidol University, Bangkok, } \\
\text { Thailand, }\end{array}$ & $\begin{array}{l}\text { Suchatlampong } \\
\text { et al. [11] }\end{array}$ & 1981 & $\begin{array}{l}\text { 67/M. LVC, anterior and posterior } \\
\text { commissure and supraglottis }\end{array}$ & DOD at 6 months \\
\hline & & & $\begin{array}{l}\text { Hoarseness and dyspnea. Mass } \\
\text { involving the glottis with } \\
\text { supraglottic extension. RT }\end{array}$ & \\
\hline \multirow[t]{4}{*}{$\begin{array}{l}\text { University of Texas, Southwestern } \\
\text { Medical School, Dallas, TX, USA }\end{array}$} & $\begin{array}{l}\text { Dahm et al. } \\
{[10]}\end{array}$ & 1978 & $\begin{array}{l}\text { 79/M. RVC and anterior } \\
\text { commissure }\end{array}$ & DOD \\
\hline & & & Hoarseness and difficulty breathing & \\
\hline & & & Polypoid mass occupying the airway & \\
\hline & & & Multiple lung metastases. LE & \\
\hline \multirow[t]{2}{*}{$\begin{array}{l}\text { State Univ. of New York, Buffalo, } \\
\text { NY, USA }\end{array}$} & Haar et al. [36] & 1978 & $\begin{array}{l}\text { 66/M. Smoker. Hoarseness. CC, } \\
\text { posterior wall of the proximal } \\
\text { trachea and displacing the } \\
\text { esophagus anteriorly }\end{array}$ & $\begin{array}{l}\text { DOD at } \\
21 \text { months }\end{array}$ \\
\hline & & & Lung metastasis. LE & \\
\hline \multirow[t]{3}{*}{$\begin{array}{l}\text { Royal Victoria Infirmary, Newcastle, } \\
\text { UK }\end{array}$} & $\begin{array}{l}\text { Morley et al. } \\
\text { [37] }\end{array}$ & 1973 & $\begin{array}{l}\text { 62/M. Hoarseness, dyspnea, acute } \\
\text { respiratory obstruction. Occasions } \\
\text { of loss of consciousness. Polypoid } \\
\text { lesion of RVC }\end{array}$ & DOD at 3 months \\
\hline & & & LVC with supraglottic extension & \\
\hline & & & Subtotal LE and RT & \\
\hline
\end{tabular}


Table 2 continued

\begin{tabular}{lllll}
\hline Institute & Authors & Year & Characteristics and treatment & Follow-up \\
\hline $\begin{array}{l}\text { Univ. of Virginia, Charlottesville, } \\
\text { VA, USA }\end{array}$ & $\begin{array}{c}\text { Sprinkle et al. } \\
{[3]}\end{array}$ & $\begin{array}{c}1966 \\
\begin{array}{l}71 / \text { M. Hoarseness. Posterior surface } \\
\text { of RVC. No metastasis. LE }\end{array}\end{array}$ & NED > 24 months \\
\hline
\end{tabular}

$F$ female, $M$ male, $O S$ osteosarcoma, $L E$ laryngectomy, $N D$ neck dissection, $T x$ treatment, $N E D$ no evidence of disease, $P Y$ pack years, $R T$ radiotherapy, $C T$ chemotherapy, $C R T$ chemoradiotherapy, $D O D$ dead of disease, $T C$ thyroid cartilage, $C C$ cricoid cartilage, $R V C$ right vocal cord, $L V C$ left vocal cord, $N D$ neck dissection

survival. In the present cases, laryngectomy was performed for 26 out of the 29 cases with treatment-related data available. Adjuvant radiotherapy needs to be considered individually, as osteosarcomas are relatively radioresistant. Chemotherapy might improve the prognosis for patients with disseminated lesions, and it should be emphasized that in the results of the present review, the number of patients with distant metastasis was high (36\%).

In the present review, five out of the 33 patients had no reported follow-up data. Eleven out of the 28 patients with follow-up data available were alive with no evidence of disease after a variable follow-up time (range 9 months to 8 years).

The important features of laryngeal osteosarcoma are summarized in Table 1. A summary of the reported laryngeal osteosarcoma cases is shown in Table 2, with the first case published in 1966 [3] and the last in 2019 [38]. Table 3 provides a description of the cases that have been reported without pathological documentation.

\section{CONCLUSIONS}

True laryngeal osteosarcoma remains an extremely rare malignancy. The true incidence of this entity is not known but based on the number of existing well-documented cases $(n=33)$ in the literature during 1966-2019, it is obviously not encountered at most of the institutions managing laryngeal tumors.

The diagnosis of this highly malignant tumor would preferably warrant an international consultation network including a registry of rare head and neck neoplasms. Electronic
Table 3 Reported cases of laryngeal osteosarcoma with no pathological documentation

\begin{tabular}{|c|c|c|}
\hline $\begin{array}{l}\text { Bennion et al. } \\
{[5]}\end{array}$ & 20 & $\begin{array}{l}\text { 48/F. Shortness of breath. } \\
\text { Erythematous mass inferior to } \\
\text { the level of the true vocal cords } \\
\text { at the posterior commissure. } \\
\text { The tumor appeared to arise } \\
\text { from the cricoid cartilage in } \\
\text { computed tomography imaging. } \\
\text { No microphotography }\end{array}$ \\
\hline $\begin{array}{l}\text { Laskin et al. } \\
\text { [8] }\end{array}$ & 1988 & $\begin{array}{l}\text { 56/M. Three years after } \\
\text { radiotherapy. No follow-up } \\
\text { data. No microphotography }\end{array}$ \\
\hline Clerf et al. [2] & 1946 & $\begin{array}{l}\text { 51/M. Hoarseness and dyspnea. } \\
\text { Later with local recurrence and } \\
\text { lung metastasis. DOD } \\
14 \text { months. Pathological } \\
\text { documentation not convincing }\end{array}$ \\
\hline $\begin{array}{l}\text { Jackson and } \\
\text { Jackson }[1]\end{array}$ & 1942 & $\begin{array}{l}\text { 51/M. Hoarseness, dyspnea, and } \\
\text { dysphagia. Cricoid cartilage. } \\
\text { Local recurrence after } 3 \text { months. } \\
\text { DOD after } 6 \text { months with } \\
\text { mediastinal metastasis. No other } \\
\text { data available }\end{array}$ \\
\hline
\end{tabular}

$F$ female, $M$ male, $D O D$ dead of disease

platforms for such activities exist. Our review demonstrates that full photomicrographic documentation is essential for the diagnosis and registration of osteosarcoma cases. Furthermore, such a collaborative effort would enable multidisciplinary recommendations for individual management as well. Naturally, management of laryngeal osteosarcoma should be 
centralized to a few experienced tertiary care academic centers.

\section{ACKNOWLEDGEMENTS}

Funding. This study was supported by the Finska Läkaresällskapet (AM) and the Helsinki University Hospital Research Fund (AM, TYH2018215). No Rapid Service Fee was received by the journal for the publication of this article.

Authorship. All named authors meet the International Committee of Medical Journal Editors (ICMJE) criteria for authorship for this article, take responsibility for the integrity of the work as a whole, and have given their approval for this version to be published.

Disclosures. The authors Antti A. Mäkitie, Kenneth O. Devaney, Bertrand Baujat, and Alhadi Almangush have nothing to disclose. Alfio Ferlito is a member of the Editorial Board of this journal but has nothing else to disclose.

Compliance with Ethics Guidelines. This article is based on previously conducted studies and does not contain any studies with human participants or animals performed by any of the authors.

Data Availability. All data generated or analyzed during this study are included in this published article.

Open Access. This article is licensed under a Creative Commons Attribution-NonCommercial 4.0 International License, which permits any non-commercial use, sharing, adaptation, distribution and reproduction in any medium or format, as long as you give appropriate credit to the original author(s) and the source, provide a link to the Creative Commons licence, and indicate if changes were made. The images or other third party material in this article are included in the article's Creative Commons licence, unless indicated otherwise in a credit line to the material. If material is not included in the article's Creative Commons licence and your intended use is not permitted by statutory regulation or exceeds the permitted use, you will need to obtain permission directly from the copyright holder. To view a copy of this licence, visit http://creativecommons.org/licenses/by$\mathrm{nc} / 4.0 /$.

\section{REFERENCES}

1. Jackson C, Jackson C. CH XXV-malignant diseases of the larynx. Diseases and injuries of the larynx. New York: Macmillan Publishing Company; 1942.

2. Clerf LN. Sarcoma of the larynx. Report of eight cases. Arch Otolaryngol. 1946;44:517-24.

3. Sprinkle PM, Allen MS, Brookshire PF. Osteosarcoma of the larynx. (A true primary sarcoma of the larynx). Laryngoscope. 1966;76:325-33.

4. Batsakis JG. Tumors of the head and neck. Clinical and pathological considerations. Baltimore: The Williams \& Wilkins Company; 1974. p. 276.

5. Bennion NR, Baine MJ, Malouff T, Zhen W. Osteosarcoma of the larynx: treatment outcomes and patterns of failure analysis. Rare Tumors. 2017;9:18-22.

6. Bahl A, George P, Bhattacharyya T, Ghoshal S, Bakshi J, Das A. Osteosarcoma of larynx: a rare case report with review of literature. J Can Res Ther. 2015;11(4):1038.

7. Mosalleum E, Afrogheh A, Stofberg S, Bezuidenhout AF, Schneider J, Hille J. A review of primary osteosarcoma of the larynx and case report. Head Neck Pathol. 2015;9:158-64.

8. Laskin WB, Silverman TA, Enzinger FM. Postradiation soft tissue sarcomas. An analysis of 53 cases. Cancer. 1988;62:2330-40.

9. Sheen TS, Wu CT, Hsieh T, Hsu MM. Postirradiation laryngeal osteosarcoma: case report and literature review. Head Neck. 1997;19:57-62.

10. Dahm LJ, Schaefer SD, Carder HM, Vellios F. Osteosarcoma of the soft tissue of the larynx: report of a case with light and electron microscopic studies. Cancer. 1978;42:2343-51.

11. Suchatlampong V, Sriumpai S, Khawcharoenporn V. Osteosarcoma of the larynx. The first case report in Thailand with ultrastructural study. J Med Assoc Thail. 1981;64:301-7. 
12. Pinsolle J, LeCluse I, Demeaux H, Laur P, Rivel J, Siberchicot F. Osteosarcoma of the soft tissue of the larynx: report of a case with electron microscopic studies. Otolaryngol Head Neck Surg. 1990;102: 276-80.

13. Michaels L. Pathology of the larynx. Berlin: Springer; 1984.

14. Saleem M, Taibah K, Gangopadhyay KJ. Osteogenic sarcoma metastasizing to the larynx. J Otolaryngol. 2002;31:189-92.

15. Shimizu KT, Selch MT, Fu YS, Anzai Y, Lufkin RB. Osteosarcoma metastatic to the larynx. Ann Otol Rhinol Laryngol. 1994;103:160-3.

16. AbdullGaffar B, Keloth T. Laryngeal sarcomas: a case series of 5 cases. Ann Diagn Pathol. 2018;37: $35-41$.

17. Sawicki P, Każmierczak W, Szylberg $€$, Marszałek A. Osteosarcoma of the larynx. Contemp Oncol (Pozn). 2015;19:246-9.

18. Kuba $\mathrm{K}$, Inoue $\mathrm{H}$, Hayashi $\mathrm{T}$, et al. Laryngeal osteosarcoma: case report and literature review. Head Neck. 2015;37:E26-9.

19. Bhatt NR, Kakked GA, Merchant R, Bhatt R. Extraskeletal osteosarcoma of the larynx: an extremely unusual tumour. BMJ Case Rep. 2014;16: 206759.

20. Ulusan M, Yilmazer R, Ozluk Y, Enoz M, Suoglu Y. Radiation-induced osteosarcoma of the larynx: case report and literature review. Ear Nose Throat J. 2012;91:E22-5.

21. Sanaat Z, Mohammady G, Esmaili H, Emrani M, Dolatkhah R. Osteosarcoma of the larynx. Arch Iran Med. 2009;12:499-502.

22. Arslan M, Orhan-Kizilkaya H, Yalcin B, et al. Larynx osteosarcoma: case report. J BUON. 2008;13:437-9.

23. Mottola G, Cascone AM, Cavaliere $\mathrm{M}$, et al. Osteosarcoma of the larynx: a case report. Cases J. 2008;1:365.

24. Rydzewski B, Matusiak M. Osteosarcoma of the larynx. Otolaryngol Pol. 2005;59:285-8.

25. Athré RS, Vories A, Mudrovich S, Ducic Y. Osteosarcomas of the larynx. Laryngoscope. 2005;115:74-7.
26. Topaloglu I, Işiksaçan V, Ulusoy S, Sişman S. Osteosarcoma of the larynx. Otolaryngol Head Neck Surg. 2004;131:789-90.

27. Madrigal FM, Godoy LM, Daboin KP, Casiraghi O, Garcia AM, Luna MA. Laryngeal osteosarcoma: a clinicopathologic analysis of four cases and comparison with a carcinosarcoma. Ann Diagn Pathol. 2002;6:1-9.

28. Rossi RM, Landas SK, Kelly DR, Marsh WL. Osteosarcoma of the larynx. Head Neck Surg. 1998;118:385-8.

29. Myssiorek D, Patel M, Wasserman P, Rofeim O. Osteosarcoma of the larynx. Ann Otol Rhinol Laryngol. 1998;107:70-4.

30. Berge JK, Kapadia SB, Myers EN. Osteosarcoma of the larynx. Arch Otolaryngol Head Neck Surg. 1998;124:207-10.

31. Devaney KO, Ferlito A. Cartilaginous and osteogenic neoplasms. In: Ferlito A, editor. The book surgical pathology of laryngeal neoplasms. London: Chapman \& Hall Medical; 1996. p. 393-424.

32. Zohar Y, Wulikh M, Aminov H, et al. Head and neck sarcoma. Harefuah. 1996;130:740-4.

33. van Laer CG, Helliwell TR, Atkinson MW, Stell PM. Osteosarcoma of the larynx. Ann Otol Rhinol Laryngol. 1989;98:971-4.

34. Remagen W, Löhr J, von Westernhagen B. Osteosarkom des Kehlkopfes. HNO. 1983;31:366-8.

35. Gorenstein A, Neel HB III, Weiland LH, Devine KD. Sarcomas of the larynx. Arch Otolaryngol. 1980;106:8-12.

36. Haar JG, Chaudhry AP, Karanjia MD, Milley PS. Chondroblastic osteosarcoma of the larynx. Arch Otolaryngol. 1978;104:477-81.

37. Morley AR, Cameron DS, Watson AJ. Osteosarcoma of the larynx. J Laryngol Otol. 1973;87:997-1003.

38. Mantilla JG, Xu H, Ricciotti RW. Primary sarcomas of the larynx: a single institutional experience with ten cases. Head Neck Pathol. 2019. https://doi.org/ 10.1007/s12105-019-01106-1 (Epub ahead of print). 